
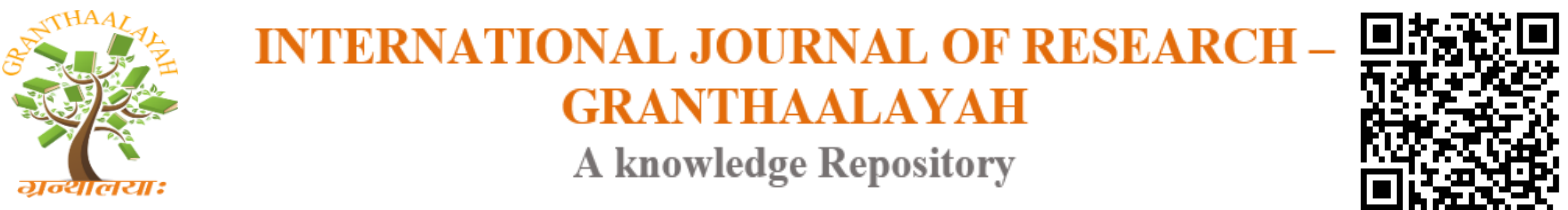

Social

\title{
PREFERENCES EXPRESSED BY STUDENTS OF NINTH STANDARD TO THE ADOPTION OF VARIED SITUATIONS IN SITUATIONAL APPROACH
}

\author{
S. Ravi ${ }^{1}$, Dr. K. Chinnappan ${ }^{2}$ \\ ${ }^{1}$ Research Scholar, Department of Education and Management, Tamil University, Thanjavur - \\ 613010, India \\ ${ }^{2}$ Professor and Head, Department of Education and Management, Tamil University, Thanjavur - \\ 613010, India
}

\begin{abstract}
The present study is aimed at assessing the preferences of ninth standard students in various situations of situational approach of English language teaching. All the ninth standard students studying in the high and higher secondary schools in Thanjavur district form the population of the study. 200 ninth standard students have chosen randomly to form the sample of the study. Percentage analysis was the only statistical technique adopted to compute the number of students preferring each situation. A rating scale for student's preference towards different situations was prepared and validated by the researcher to collect data. The percentage analysis of the collected data reveals that real life situations are the most preferred situation from the situational approach by ninth standard students; whereas verbal situation is the least preferred by them. Male students, Students from rural area, Students from government and aided schools have more preference towards real life situations; whereas female students, Students from urban area, Students from private schools shown preference towards classroom situations. Without any difference, all the category of students prefers verbal situations as the least effective situations of situational approach of teaching learning process. These findings may be handy in making aware of teachers to use various situations to teach language in the classrooms.
\end{abstract}

Keywords: Students; Education; Situational Approach.

Cite This Article: S. Ravi, and Dr. K. Chinnappan. (2017). "PREFERENCES EXPRESSED BY STUDENTS OF NINTH STANDARD TO THE ADOPTION OF VARIED SITUATIONS IN SITUATIONAL APPROACH." International Journal of Research - Granthaalayah, 5(8:SE), 34-39. https://doi.org/10.29121/granthaalayah.v5.i8(SE).2017.2244.

\section{Introduction}

In spite of the controversies on language learning processes, there is the underlying fact that the main practical objective of teaching a language is to enable the learners to use it. That is, to know to what real-life situations each particular form of the target language corresponds. This leads us 
to the term "approach" which according to Edward M Anthony is "a set of correlative assumptions dealing with the nature of language teaching and learning." According to this definition, any approach is basically a collection of intrinsic beliefs which serve as a framework to a specific outlook on language (Knorre, Marty, et al, 1977). Developed by British applied linguists in the 1930s, the Situational Approach has survived, so far, by completing later approaches and methodologies such as Audio-Lingual Method, Communicative Language Teaching, Total Physical Response, The Silent Way, Community Language Learning, The Natural Approach, Suggestopedia., etc. (Richards, Jack C \& Theodore S. Rodgers.,1986).

The theory backing up the Situational Approach includes the following principles: language learning is habit-formation, mistakes are bad and should be avoided, as they make bad habits, language skills are learned more effectively if they are presented orally first, then in written form, analogy is a better foundation for language learning than analysis, the meanings of words can be learned only in a linguistic and cultural context (Byrne Donn, 1969). The situational approach of English language teaching reflects market behaviour, it is widely used and understood, it is accorded greatest weight by the courts, it requires least adjustment if sufficient data is available (Gagne Robert, 1965).

\section{Need for the Study}

The main characteristics of the approach were as follows: Language teaching begins with the spoken language. Material is taught orally before it is presented in written form, The target language is the language of the classroom, New language points are introduced and practiced situationally, Vocabulary selection procedures are followed to ensure that an essential general service vocabulary is covered, Items of grammar are graded following the principle that simple forms should be taught before complex ones, Reading and writing are introduced once a sufficient lexical and grammatical basis is established (Linguistik (2017). The best results from this approach are obtained when good and truly comparable properties are used. The best comparables are those which require the least amount of adjustment. The best comparison can be made when the selling price is reduced to a proper unit of comparison. Adjustments are then made to the sale price per unit. It is always best to make any necessary time adjustments first, and then apply the total of all other adjustments to the time adjusted price per unit to arrive at a fully adjusted price per unit from each comparable (Blount, et al, 1968).

Though situational approach is not a very new approach of English language teaching, still it has its scope in teaching the languages by offering various kinds of situations to learn the structure and usage of the language. It is quite natural that a competent teacher can adopt number of situations from various sources such as classroom situations, real life situations, pictorial situations, and verbal situations, etc. from all these kinds of situations prompted for teaching a language, none of the situation may blindly treated as a highly significant one, since each one has its role in teaching the language. Verbal situations which is generally not attracting easily the students too has it applications in which other kinds of situations may not be applicable when we are dealing with many abstract qualities and things. Since the researcher felt that each situation has its role in teaching language to students, but the preference exhibited by the students towards the situations may made significant effect in making the situations effective in teaching and learning process of the language (Billows, F.L, 1961). Thus, the preset study was undertaken by 
the researcher with the intention to study the preference shown by the students towards the four kinds of situations offered in situational approach for teaching English language which may be helping the teachers to understand its effectiveness and attracting capacity towards students which ultimately a factor to determining the effectiveness of learning process.

\section{Objectives}

- To identify the ninth standard students' most preferred situation for teaching English.

- To identify the ninth standard students' most preferred situation for teaching English in terms of gender.

- To identify the ninth standard students' most preferred situation for teaching English in terms of locality.

- To identify the ninth standard students' most preferred situation for teaching English in terms of type of school.

\section{Hypotheses}

- The ninth standard students prefer all the situations of situational approach of teaching equally.

- The ninth standard students prefer all the situations of situational approach of teaching equally in terms of gender.

- The ninth standard students prefer all the situations of situational approach of teaching equally in terms of locality.

- The ninth standard students prefer all the situations of situational approach of teaching equally in terms of type of school.

\section{Population and Sample}

All the students studying ninth standard in the high and higher secondary schools in Thanjavur district form the population of the study.

About $1 \%$ of the population chosen randomly after due stratification will constitute the sample of the study. The final sample consists of 200 ninth standard students chosen randomly from the schools located in rural and urban locality.

\section{Method}

The stated problem demands quantitative data by adopting Survey method of research, suitable for percentage analysis.

\section{Research Tools}

Students' Preference Rating Scale for Different Situational Teaching -Prepared and Validated by the Researcher was administered for collecting relevant data from the ninth standard students. 


\section{Analysis of Data}

\section{Hypothesis 1}

The ninth standard students prefer all the situations of situational approach of teaching equally.

Table 1: Preference of situations in situational approach by ninth standard students

\begin{tabular}{|l|l|l|l|l|l|l|l|l|}
\hline \multirow{2}{*}{$\begin{array}{l}\text { No. of } \\
\text { Students }\end{array}$} & \multicolumn{2}{l|}{$\begin{array}{l}\text { Classroom } \\
\text { Situations }\end{array}$} & \multicolumn{2}{|l|}{ Real life situations } & $\begin{array}{l}\text { Pictorial } \\
\text { situations }\end{array}$ & \multicolumn{2}{l|}{ Verbal situations } \\
\cline { 2 - 9 } & $\mathbf{N}$ & $\mathbf{\%}$ & $\mathbf{N}$ & $\mathbf{0}$ & $\mathbf{N}$ & $\mathbf{\%}$ & $\mathbf{N}$ & $\%$ \\
\hline $\mathbf{2 0 0}$ & 59 & 29.5 & 62 & $31.0 *$ & 49 & 24.5 & 30 & 15.0 \\
\hline
\end{tabular}

* indicates the most preferred situation

\section{Hypothesis 2}

The ninth standard students prefer all the situations of situational approach of teaching equally in terms of gender.

Table 2: Preference of situations in situational approach by ninth standard students in terms of gender

\begin{tabular}{|l|l|l|l|l|l|l|l|l|l|}
\hline \multirow{2}{*}{ Gender } & \multirow{2}{*}{$\begin{array}{l}\text { No. of } \\
\text { Students }\end{array}$} & \multicolumn{2}{l|}{$\begin{array}{l}\text { Classroom } \\
\text { Situations }\end{array}$} & \multicolumn{2}{l|}{$\begin{array}{l}\text { Real life } \\
\text { situations }\end{array}$} & $\begin{array}{l}\text { Pictorial } \\
\text { situations }\end{array}$ & \multicolumn{2}{l|}{$\begin{array}{l}\text { Verbal } \\
\text { situations }\end{array}$} \\
\cline { 5 - 11 } & & $\mathbf{N}$ & $\mathbf{\%}$ & $\mathbf{N}$ & $\mathbf{\%}$ & $\mathbf{N}$ & $\mathbf{\%}$ & $\mathbf{N}$ & $\mathbf{\%}$ \\
\hline Male & $\mathbf{9 3}$ & 25 & 26.9 & 29 & $31.2^{*}$ & 21 & 22.6 & 18 & 19.3 \\
\hline Female & $\mathbf{1 0 7}$ & 31 & $28.9 *$ & 27 & 25.2 & 26 & 24.3 & 23 & 21.5 \\
\hline
\end{tabular}

* indicates the most preferred situation

\section{Hypothesis 3}

The ninth standard students prefer all the situations of situational approach of teaching equally in terms of locality.

Table 3: Preference of situations in situational approach by ninth standard students in terms of

\begin{tabular}{|l|l|l|l|l|l|l|l|l|l|}
\hline \multirow{2}{*}{ Locality } & \multirow{2}{*}{$\begin{array}{l}\text { No. of } \\
\text { Students }\end{array}$} & \multicolumn{2}{l|}{$\begin{array}{l}\text { Classroom } \\
\text { Situations }\end{array}$} & \multicolumn{2}{|l|}{$\begin{array}{l}\text { Real life } \\
\text { situations }\end{array}$} & \multicolumn{2}{l|}{$\begin{array}{l}\text { Pictorial } \\
\text { situations }\end{array}$} & \multicolumn{2}{l|}{$\begin{array}{l}\text { Verbal } \\
\text { situations }\end{array}$} \\
\cline { 5 - 11 } & $\mathbf{N}$ & $\mathbf{\%}$ & $\mathbf{N}$ & $\mathbf{\%}$ & $\mathbf{N}$ & $\mathbf{\%}$ & $\mathbf{N}$ & \% \\
\hline Rural & $\mathbf{1 0 8}$ & 29 & 26.8 & 34 & $31.5^{*}$ & 27 & 25.0 & 18 & 16.6 \\
\hline Urban & $\mathbf{9 5}$ & 28 & $29.5^{*}$ & 26 & 27.4 & 23 & 24.2 & 18 & 18.9 \\
\hline
\end{tabular}

* indicates the most preferred situation

\section{Hypothesis 4}

The ninth standard students prefer all the situations of situational approach of teaching equally in terms of type of school. 
Table 4: Preference of situations in situational approach by ninth standard students in terms of

\begin{tabular}{|l|l|l|l|l|l|l|l|l|l|}
\hline \multirow{2}{*}{$\begin{array}{l}\text { Type } \\
\text { of } \\
\text { school }\end{array}$} & \multirow{2}{*}{$\begin{array}{l}\text { No. of } \\
\text { Students }\end{array}$} & $\begin{array}{l}\text { Classroom } \\
\text { Situations }\end{array}$ & \multicolumn{2}{l}{$\begin{array}{l}\text { Real } \\
\text { situations }\end{array}$} & $\begin{array}{l}\text { Pictorial } \\
\text { situations }\end{array}$ & \multicolumn{2}{l}{$\begin{array}{l}\text { Verbal } \\
\text { situations }\end{array}$} \\
\cline { 3 - 10 } Govt. & $\mathbf{7 5}$ & 19 & 25.3 & 24 & $32.0^{*}$ & 19 & 25.3 & 13 & 17.3 \\
\hline Aided & $\mathbf{6 5}$ & 17 & 26.2 & 21 & $32.3 *$ & 17 & 26.2 & 10 & 15.4 \\
\hline Private & $\mathbf{6 0}$ & 18 & $30.0 *$ & 16 & 16.6 & 15 & 25.0 & 11 & 18.3 \\
\hline
\end{tabular}

* indicates the most preferred situation

\section{Findings}

The followings are the findings deduced from statistical analysis of the data:

1) The percentage analysis of the collected data reveals that real life situations are the most preferred situation from the situational approach by ninth standard students; whereas verbal situation is the least preferred by them.

2) The analysis of data in terms of gender shows that ninth standard male and female students are found to prefer real life situations, and classroom situations respectively.

3) Locality wise analysis of data reveal that rural and urban ninth standard students are found to prefer real life situations and classroom situations of situational approach respectively.

4) Analysis of data in terms of type of school made clear that ninth standard students from government and aided schools are found to prefer real life situations; whereas the students from aided schools are found to prefer classroom situations.

\section{Discussion and Conclusion}

The present study was undertaken by the researcher with the intension to establish the most preferable as well as least preferable situations provided by the situational approach of English language teaching. It is already established that none can replace or equally effective to a real object or real situation. Whatever the pictorial expressions provided, verbal expressions delivered, or situations created or arranged in the classroom or nearby place, it cannot be equal to visit a real place by which an ultimate learning can happen. The finding arrived by the overall analysis of data goes in line with the assumptions made by the researcher that the real life situations are the most preferable situation of situation approach in English language teaching by ninth standard students. On other hand, verbal situation is the least preferred situation by ninth standard students. From this we can arrive at a conclusion that whatever the technological instruments, devices and opportunities available to describe a situation, it cannot be same with a learning inculcated from a real life situation. Verbal descriptions are merely an explanation of situation by which most of the students get bored and have less understanding and learning.

Gender wise analysis of the data shows that male students found to prefer real life situations; whereas female students are fond of classroom situations. It may be just because of the interest and thirst of male students to be in a real condition to learn; the hurdles female students may face to move around the society. In the same tone, ninth standard students from rural area, 
government and aided schools are found to prefer real life situation; whereas urban area ninth standard students, students from private schools are interested with classroom situations. It may be because of the opportunities they receive to deal in a real life situations and possibility for facing and dealing with most of the real situations easily by rural area as well as government and aided school students. In the case of urban area as well as private school students who are mostly the same population who have less opportunity to face and interact with the real situations because of the life difficulties they face. The noteworthy finding arrived from the present research is that the verbal situation is the least preferred situation by all the category of ninth standard students which implies that it is very less effective and to be avoided wherever possible. It may be applied only when there is no other option to deal with the content matter other than verbal situation in an exceptional condition.

\section{References}

[1] Billows, F.L. 1961. The Techniques of Language Teaching (London: Longman Group Ltd.).

[2] Blount, Nathan S. \& Klausmeir, Herbert J. 1968. Teaching in Secondary School (New York: Harper \& Rowe).

[3] Byrne Donn, ed. 1969. English Teaching Extracts (Singapore: Longman Group Ltd.)

[4] Gagné Robert. 1965. The Conditions of Learning (New York: Holt, Rinehart \&Winston)

[5] Golden, S. A. R. (2011). Problems and Prospectus of Distance Education. Quality Enhancement In Distance Education For Life Long Learning, 1(1), 343-344.

[6] Golden, S. A. R. (2016). Rural Students'attitude Towards English As Medium Of Instruction In Higher Education-An Analysis. International Journal of Research, 3, 1-10.

[7] Golden, S. A. R. (2017). Attitude of Students and Teachers towards E-Learning-An Analysis. Recent Research in Social Science \& Humanities, 1, 5-10.

[8] Knorre, Marty et al. 1977. Cara a Cara (New York : Holt, Rinehart \& Winston).

[9] Linguistik (2017). The Oral Approach and Situational Language Teaching <http://linguistikid. $\mathrm{com} /$ oral-approach-and-situational-language-teaching/>

[10] Regi, S. B., \& Golden, S. A. R. (2014). A Study On Educational Loan Availed By Students In Trichy City. Journal Of International Academic Research For Multidisciplinary (Jiarm), 2 (1).

[11] Richards, Jack C \& Theodore S. Rodgers. (1986). Approaches and Methods In Language Teaching: A description and analysis. UK: Cambridge University Press. 